(C) The Oceanographic Society of Japan and Springer 2011

\title{
Biological productivity enhancement over a continental shelf break (Bay of Biscay, NE Atlantic) evidenced by mesozooplankton aspartate transcarbamylase activity
}

\author{
Jean-Pierre Bergeron ${ }^{1,{ }^{*}}$ and Noussithé Koueta ${ }^{2}$
}

\author{
${ }^{1}$ IFREMER (Institut Français de Recherche pour l'Exploitation de la MER), Centre Atlantique, \\ Département Ecologie et Modèles pour l'Halieutique (EMH), B.P. 21105, 44311 Nantes Cedex 03, \\ France \\ ${ }^{2}$ Université de Caen, Laboratoire de Biologie et Biotechnologies Marines, Esplanade de la Paix, \\ 14032 Caen Cedex, France \\ *: Corresponding author : Jean-Pierre Bergeron, Tel: 332 40374162; fax: 332 40374075, email \\ address : jean.pierre.bergeron@ifremer.fr
}

\begin{abstract}
:
During spring 2005, satellite imagery revealed high sea surface chlorophyll a concentrations over the edge of a wide continental shelf in the Bay of Biscay (NE Atlantic). As a descriptor of biological productivity, mesozooplankton aspartate transcarbamylase specific activity was measured in situ during the bloom. Notably high values were detected in the bloom area relative to other parts of the study area.
\end{abstract}

Keywords: Aspartate transcarbamylase - Chlorophyll a - Mesozooplankton - Satellite imagery Continental shelf break - Bay of Biscay 


\section{Introduction}

The accumulation of numerous compartments of the pelagic food web near the continental shelf edge and over the shelf break is a well-known phenomenon throughout the world ocean. From phytoplankton (e.g., Lampert et al., 2002) to numerous fish species (e.g., Uriarte and Lucio, 2001) and up to highest trophic levels, i.e. direct human's competitors such as birds (Certain et al., 2007) and large mammals (Certain et al., 2008), this biocenosis benefits from inorganic nutrients supplied by physical forcings (New and Pingree, 1990; Gerkema et al., 2004). Among such communities, the zooplankton play a pivotal role (sensu Banse, 1995) in the control of ocean production.

Within the framework of a small pelagic fish ecology programme, mesozooplankton samples have been systematically taken following a regular sampling design that covers the whole French part of the continental shelf of the Bay of Biscay (NE Atlantic). These samples were analysed for the activity of the enzyme aspartate transcarbamylase (ATC), which is involved in metabolic control of growth at the cellular level (Jones, 1980; Bergeron and Alayse-Danet, 1981). At the community level, and according to the"ataxonomic approach" defended by certain authors (e.g., González and Quiñones, 2009), quantitative variation of this enzyme's activity is considered to be a proxy for mesozooplankton overall productivity (Bergeron et al., 2009; 2010). During the spring of 2005, satellite imagery revealed high concentrations of chlorophyll a along the Bay of Biscay shelf break. These high concentrations were accompanied by a significant increase in ATC specific activities in mesozooplankton. This phenomenon, for the first time evidenced through an objective biochemical tool on the mesozooplankton community level, is described herein. 


\section{Materials and methods}

The PELGAS.05 research cruise, which was devoted to the study of the abundance and spatial distribution of small pelagic fishes using acoustic tools (Scalabrin and Massé, 1993), occurred from May 4 to May 31, 2005 aboard the RV Thalassa. The cruise covered the entire French part of the continental shelf of the Bay of Biscay (i.e., a little more than $4^{\circ}$ in latitude). The mesozooplankton sampling, which was conducted from May 5 to May 25 , occurred at stations located along transects that ran roughly perpendicular to the coastline. A total of 43 mesozooplankton samples were collected (Figure 1).

Mesozooplankton samples were collected by $50 \mathrm{~cm} \mathrm{sec}^{-1}$ vertical tows with a WP2 net (200- $\mu \mathrm{m}$ mesh size) from $5 \mathrm{~m}$ above the bottom (or from $200 \mathrm{~m}$ depth in the case of the few stations located in the oceanic province) to the surface. On board the ship, samples were sieved through a 5-mm mesh to separate the macrozooplankton. The mesozooplankton in the filtrate were homogenised in iced distilled water using a Polytron ${ }^{\circledR}$ grinder. Next, 2.5-ml aliquots were immediately frozen in liquid nitrogen, where they were kept until the end of the cruise. Thereafter, they were stored at $-80{ }^{\circ} \mathrm{C}$ until analysis in the laboratory, as this storage procedure does not introduce any significant change in enzymatic activities (Biegala and Bergeron, 1998). After thawing, the crude extract was homogenised again using a Potter-Elvehjem tissue grinder, and a $200-\mu 1$ aliquot of the resulting homogenate was used for the ATC activity assay according to the method initially described by Bergeron and Alayse-Danet (1981) and revised by Biegala and Bergeron (1998). Each sample was assayed in triplicate. ATC specific activity is expressed in nM CA (carbamylaspartate) produced $\mathrm{min}^{-1} \mathrm{mg}^{-1}$ protein. To quantify the amount of protein present, Lowry et al.'s (1951) method was used, with bovine serum albumin as the standard.

The satellite imagery of the sea surface in the Bay of Biscay was obtained from the NAUSICAA server for the Northwestern European shelves, which is administered by IFREMER (http://www.ifremer.fr/nausicaa2/marcoast/index.htm). The NASA space sensor SeaWiFS provides ocean colour images, from which chlorophyll a concentrations can be inferred from water-leaving radiance estimates (Gohin et al., 2002). Moreover, images provided by satellites brought precious insights into basic phenomena involved in first steps of pelagic biological productivity such as sea surface temperature anomalies and solar irradiance: for these aspects, we got NOAA/AVHRR data and METEOSAT-7 data respectively thanks to the NAUSICAA server, details about processing these data are given in Gohin et al. (2003). We retained data got a few days before the beginning of the cruise because a time lag is necessary between occurrence of a whole of physical driving forces conditioning the appearance of a defined ecological context and the appearance of the effect on 
higher trophic level, i.e. in the present case on the metabolism of the mesozooplankton community (e.g.

Mayzaud and Poulet, 1978). We defined for this study the $2^{\text {nd }}$ of May 2005.

In Figure 1, ATC specific activities are presented as square symbols. Four classes of values were arbitrarily defined according to the distribution of these values in each class in order to have a well-balanced distribution. 


\section{Results and discussion}

Phytoplakton cells are the smallest living particles of the pelagic food web that may be spotted by satellites, owing to their natural radiance linked to chlorophyll a. Also phytoplankton cells' growth requires the conjunction of at least two assential factors: supply of nutrients and solar irradiation in sufficient quantities.

In 2005, over the Bay of Biscay's continental shelf, from the coastline to the $200 \mathrm{~m}$ isobath, chlorophyll a is concentrated both in coastal areas and over the continental slope (Fig. 1). In coastal areas, it conforms to a classical pattern near the river mouths, but to a lesser degree than in previous years (e.g., 2001) during the same spring period (Bergeron et al., 2010). High chlorophyll a concentrations are also revealed by the sea surface colour over the shelf break (as indicated by the $200 \mathrm{~m}$ isobath). Enhanced primary productivity is due to nutrient enrichment caused by river outflows near the coast and by nutrient-enriched upwelled deep water over the shelf break (Pichon and Correard, 2006): this cold deep water may be viewed as a sea surface temperature anomaly (Fig. 2a) and the phytoplankton bloom is strongly enhanced by an outstanding solar irradiance oscillating between 285 and 315 W.m ${ }^{-2}$ (Fig. 2b), which lasted quasi-continuously until the end of the cruise (not shown, but ascertainable on the NAUSICAA server of IFREMER, see "Material and Methods" section for address).

Based on the spatial distribution of mesozooplankton ATC specific activities measured in the spring of 2005, the Bay of Biscay could be roughly divided into two main areas (Fig. 1): the southern part, where activities were fairly homogeneous, small, or moderate, and the northwestern part, where both weak activities as well as the strongest ones were measured.

In the northwestern part of the study area over or slightly beyond the $200 \mathrm{~m}$ isobath in the offshore direction, the ATC activities were among the highest observed (Fig. 1). Samples collected at three stations located over or near the continental slope and where sea surface temperature revealed upwelled water (Fig. 2a) gave an ATC specific activity mean value (mean $=5.99, \mathrm{SD}=1.55, \mathrm{n}=3$ ) clearly higher than the mean value calculated for all of the 43 stations sampled during the cruise (mean $=1.86, \mathrm{SD}=1.62, \mathrm{n}=43$ ).

At another one of these strong activity areas, located alone at the mid-shelf (about $46^{\circ} 12 \mathrm{~N}-2^{\circ} 25 \mathrm{~W}$ ), ATC specific activity reached $5.35 \mathrm{nM} \mathrm{CA} \mathrm{mg} \mathrm{protein}{ }^{-1}$. This rather high value occurred at a special station located over the "Plateau de Rochebonne", which is an underwater plateau indicated by an uneven line of the $50 \mathrm{~m}$ isobath (Fig. 1): It is a small but famous place for fishermen and underwater hunters. Most probably this topographic anomaly on the sea floor encounters residual current (Koutsikopoulos and Le Cann, 1996), creating turbulence, and a local increase in biological productivity, which is illustrated by this high ATC specific activity. 
On a totally different scale, such sea floor anomalies could be compared to the seamounts in oceanic regions and their biological effects (e.g., Aristegui et al., 2009).

A subtitle for this short article could have been: "When insufficient quantities of freshwater are discharged by rivers, is there an alternative source of enrichment for the Bay of Biscay pelagic ecosystem?" The reply would have been positive in the spring of 2005 because upwelled waters along the shelf break apparently introduced enough nutrients to enhance the mesozooplankton productivity. The supply of nutrients prevailed over river outflows, which ordinarily are more abundant. River outflow usually varies between 1000 and 2500 $\mathrm{m}^{3} . \mathrm{s}^{-1}$, with much higher peaks in the winter-spring transition period; in 2005, however, the flow varied between 500 and $1000 \mathrm{~m}^{3} \cdot \mathrm{s}^{-1}$ (Bergeron et al., unpublished data). In contrast to the situation in 2005, during a research cruise carried out in 2002 in similar conditions, neither river outflow rates nor along slope upwelled waters supplied enough nutrients to enhance the mesozooplankton productivity. The mean ATC specific activity value for the whole Bay of Biscay (47 sampled stations) was only 0.23 , i.e., very weak.

In summary, these results confirm the feasibility of using ATC activity measurements to detect enrichment of the trophic environment of the mesozooplankton community, to describe the spatial variability of mesozooplankton metabolism during a research cruise, and to evaluate interannual fluctuations of the overall mesozooplankton productivity in the Bay of Biscay and the possible applications of such fluctuations to small pelagic fish ecology studies. 


\section{Acknowledgements}

We are greatly indebted to Paul Bourriau and Daniel Halgand of the EMH Department for their help in field sampling and sample processing, Cathy Dejouy for drawing the figure. Thanks are due to Jacques Massé, manager of the IFREMER Project "Ecologie des Petits Pélagiques", and to the captain, officers, and crew of the RV Thalassa. This study was conducted within the framework of the FOREVAR Project, a French contribution to the GLOBEC (SPACC) International Programme. It was also carried out with the financial support of the French "Programme National d'Ecologie Côtière"/atelier Gascogne (PNEC-Gascogne), and the fisheries research part of the survey was partially financed by the European Commission, DG XIV, under the research project PELASSES n $99 / 010$. 


\section{References}

Arístegui J, Mendonça A, Vilas JC, Espino M, Polo I, Montero MF, Martins A (2009) Plankton metabolic balance at two North Atlantic seamounts. Deep Sea Res II 56:2646-2655.

Banse K (1995) Zooplankton: pivotal role in the control of ocean production. ICES J Mar Sci 52:265-277.

Bergeron J-P, Alayse-Danet A-M (1981) Aspartate transcarbamylase de la coquille Saint-Jacques Pecten maximus L. (Mollusque Lamellibranche): méthode de dosage et variations de l'activité dans le manteau et la gonade. J Exp Mar Biol Ecol 50:99-117.

Bergeron J-P, Delmas D, Koueta N (2009) Determining how the pelagic ecosystem over the continental shelf of the Bay of Biscay (NE Atlantic) functions: An approach using mesozooplakton enzymes activities as descriptors. Estuar Coast Shelf Sci 82:254-264.

Bergeron J-P, Delmas D, Koueta N (2010) Do river discharge rates drive the overall functioning of the pelagic ecosystem over the continental shelf of the Bay of Biscay (NE Atlantic)? A comparison of two contrasting years with special reference to anchovy (Engraulis encrasicolus L.) nutritional state. J Oceanogr 66:621631.

Biegala IC, Bergeron J-P (1998) Optimal assay conditions for aspartate transcarbamylase (ATCase) activity in mesozooplankton. J Plankton Res 20:1205-1218.

Certain G, Bellier E, Planque B, Bretagnolle V (2007) Characterising the temporal variability of the spatial distribution of animals: An application to seabirds at sea. Ecography 30:695-708.

Certain G, Ridoux V, van Canneyt O, Bretagnolle V (2008) Delphinid spatial distribution and abundance estimates over the shelf of the Bay of Biscay. ICES J Mar Sci 65:656-666.

Gerkema T, Lam F-PA, Maas LRM (2004) Internal tides in the Bay of Biscay: Conversion rates and seasonal effects. Deep Sea Res II 51:2995-3008.

Gohin F, Druon JN, Lampert L (2002) A five channel chlorophyll concentration algorithm applied to SeaWiFS data processed by SeaDAS in coastal waters. Int J Remote Sensing 23:1639-1661.

Gohin F, Lampert L, Guillaud J-F, Herbland A, Nézan E (2003) Satellite and in situ observations of a late winter phytoplankton bloom, in the northern Bay of Biascay. Cont Shelf Res 23:1117-1141.

González RR, Quiñones RA (2009) Common catabolic enzyme patterns in a microplankton community of the Humboldt Current System off northern nd central-south Chile: Malate dehydrogenase activity as an index of water-column metabolism in an oxygen minimum zone. Deep Sea Res II 56:1095-1104.

Jones ME (1980) Pyrimidine nucleotide biosynthesis in animals: genes, enzymes, and regulation of UMP biosynthesis. Ann Rev Biochem 49:253-279.

Lampert L, Quéguiner B, Labasque L, Pichon A, Lebreton N (2002) Spatial variability of phytoplakton composition and biomass on the eastern continental shelf of the Bay of Biscay (north-east Atlantic Ocean). Evidence of a bloom of Emiliania huxleyi (Prymnesiophyceae) in spring 1998. Cont Shelf Res 22:12251247.

Lowry OH, Rosebrough NJ, Farr AL, Randall RJ (1951) Protein measurement with Folin-phenol reagent. J Biol Chem 193:265-275.

Mayzaud P, Poulet SA (1978) The importance of the time factor in the response of zooplankton to varying concentrations of naturally occurring particulate matter Limnol Oceanogr 23:1144-1154.

New AL, Pingree RD (1990) Evidence for internal tidal mixing near the shelf break in the Bay of Biscay. Deep Sea Res 37:1783-1803.

Pichon A, Correard S (2006) Internal tides modelling in the Bay of Biscay. Comparisons with observations. Sci Mar 70:65-88.

Scalabrin C, Massé J (1993) Acoustic detection of the spatial and temporal distribution of fish shoals in the Bay of Biscay. Aquat Living Resour 6:269-283.

Uriarte A, Lucio P (2001) Migration of adult mackerel along the Atlantic European shelf edge from a tagging experiment in the south of the Bay of Biscay in 1994. Fish Res 50:129-139. 


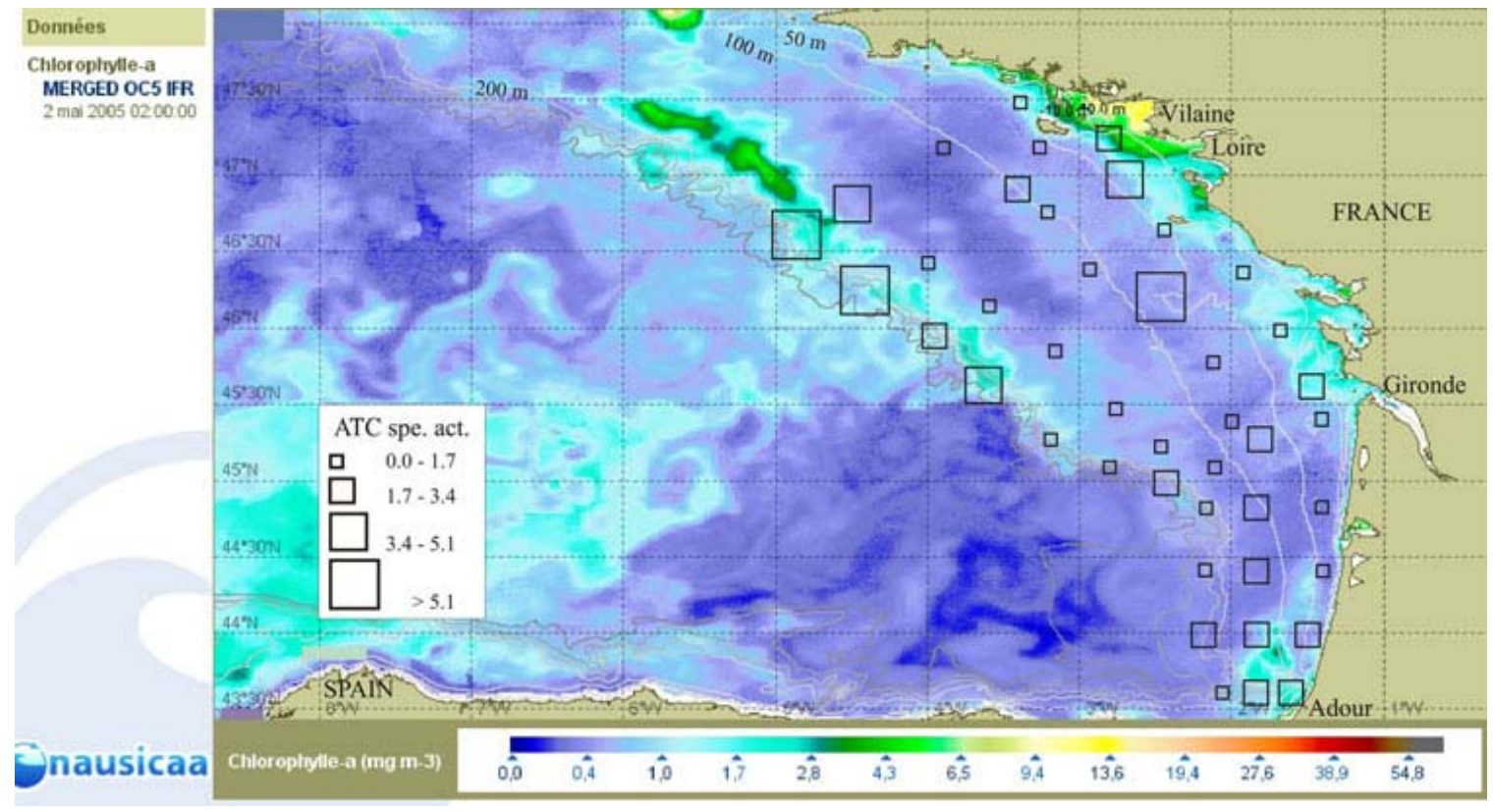

Fig. 1 Overview of the sea surface colour of the Bay of Biscay provided by the space sensor SeaWiFS, which recorded the water-leaving radiance from chlorophyll a concentrations. Locations of the 43 stations where ATC specific activities (expressed in $\mathrm{nMCA} \mathrm{mg}$ protein $^{-1}$ ) were measured are presented as square symbols belonging to the four classes of values defined in the inset

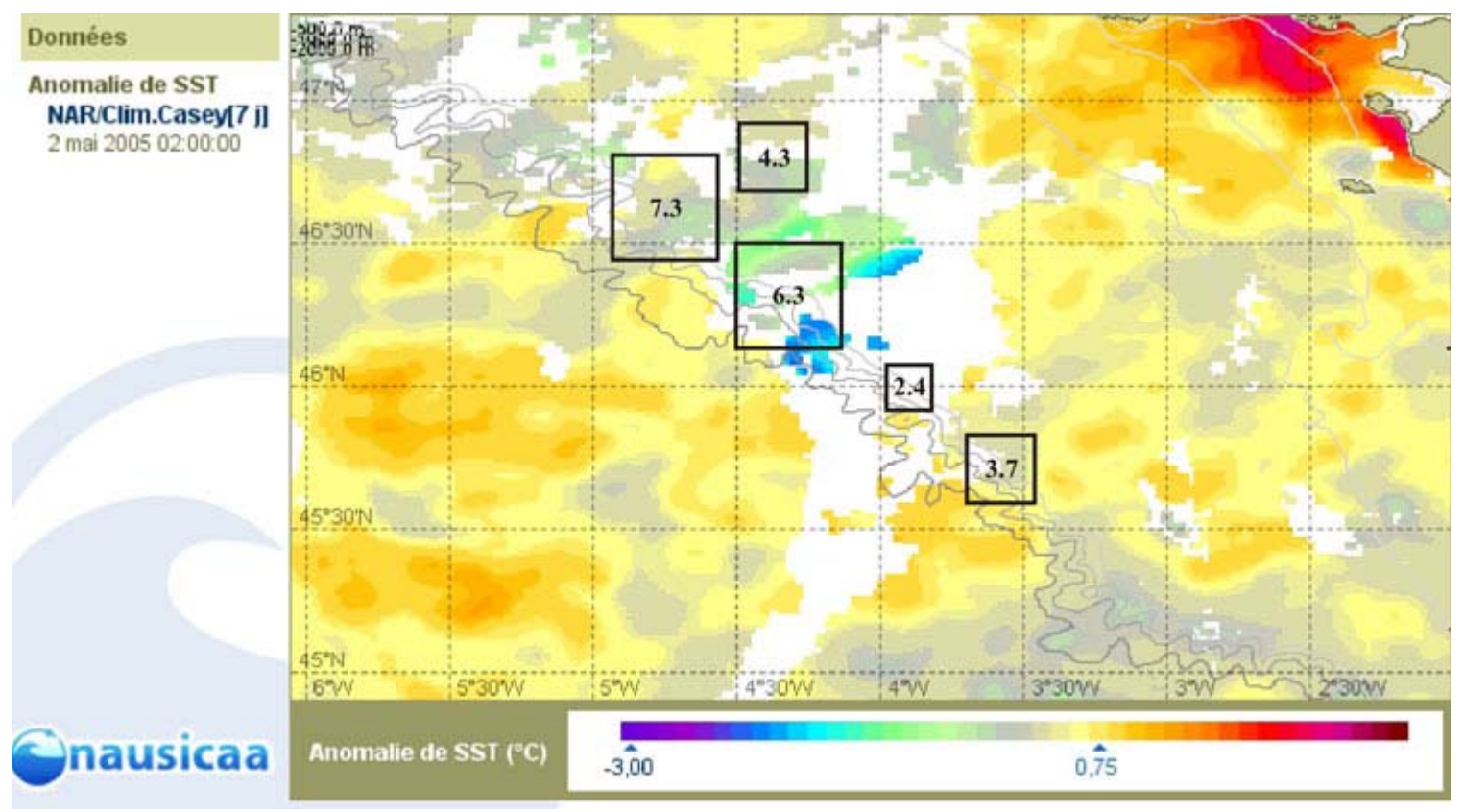

Fig. 2 Overview of sea surface temperature anomalies in the Bay of Biscay (light green from -0.95 to $-1.20^{\circ} \mathrm{C}$; light blue from -1.50 to $-1.65^{\circ} \mathrm{C}$; dark blue from -1.80 to $-1.95^{\circ} \mathrm{C}$; the red area at the top indicates hotter continental water flowing out of the Loire River) and zones of the region located over the continental shelf slope, where highest ATC activity values, pointed out in each square, were measured in mesozooplankton samples 